\title{
(In)efficiency of EU Common Foreign and Security Policy: Ukraine, Brexit, Trump and beyond
}

\section{Ondřej Filipec ${ }^{1}$}

\begin{abstract}
The main aim of this article is to explore and analyze key determinants of EU Common Foreign and Security Policy efficiency. For this purpose a 3C analytical approach is used, exploring EU foreign and security policy consistency, capacities and the dimension of cooperation. Article analyzes both horizontal and vertical, consistency of EU Foreign and Security policy especially with connection to Ukraine crises and diverging interests of EU member states. EU capacities are explored with main focus on military spending and challenges related to limited spending. EU military decline is put in contrast with new emerging regional powers. In the area of cooperation article is dedicated mainly to ineffective partnership with Turkey, cold attitude of Trump administration towards Europe and the implications of Brexit for EU foreign and security policy.
\end{abstract}

Key Words: EU, CFSP, CSDP, Brexit, Trump, Foreign Policy efficiency

\section{INTRODUCTION}

In 1992 when European integration proceeded into the area of foreign and security policy there was positive spirit about the future of the EU cooperation marked by the adoption of Maastricht treaty. Henry Kissinger (1994) very well pointed out that because any European state is not able to take lead in international affairs, then all countries tries to dedicate a lot of energy to compensate relative weakness by integration. If European states succeed, there will be no norm for EU behaviour on the global scene because such a political entity never existed (Kissinger, 1994). In other words, there will be new space for EU to define its identity and role within new world order.

Following war in former Yugoslavia revealed institutional and political weakness of the EU cooperation and Amsterdam treaty only partly addressed deficiencies in the field. EU enlargement in 2004 opened new dimension within EU foreign policy and contributed to increase in diversity of perspectives within foreign policy. Far from being perfect EU Common Foreign and Security policy (SFSP) and its European Security and Defence Policy (ESDP) element undertaken changes. Today EU foreign and security policy faces unprecedented

\footnotetext{
${ }^{1}$ Assistant professor, Dept. of Politics and European Studies, Faculty of Social Sciences, University of Ss. Cyril and Methodius in Trnava, Bučianska 4/A, 91701 Trnava, Slovak republic, e-mail: ondrejfilipec@gmail.com.
} 
challenges strongly influencing its efficiency.

The main aim of this paper is to explore and analyzes current challenges of EU foreign and security policy and its impact on EU foreign and security policy effectiveness. The principal claim is that there are gaps within both consistency and capacities of EU foreign and security policy and new challenges in cooperation for cooperation patterns which may result in EU Common Foreign and Security Policy inefficiency and underperformance.

For the purpose of complex analysis article focuses on three key factors: policy consistency, capacities and cooperation with main actors. The 3 " $\mathrm{C}$ " shall be considered as main determinants of foreign and security policy effectiveness and thus basic framework for analysis, as presented on the picture 1 .

Picture 1: Key determinants of foreign and security policy efficiency

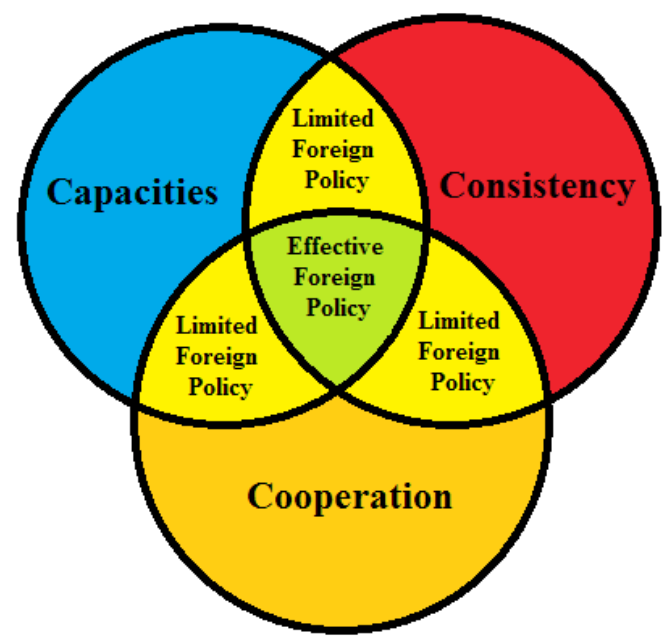

Source: Author, own elaboration

There is a ongoing debate about the meaning and measurement of coherence or consistency. As pointed out by Daniel C. Thomas (2012), scholars disagree about the content behind of coherence. Some focus on EU institutors, others on policy makers, rhetoric, policy making process or policy outcomes. Moreover, French term cohérence is being translated into English as consistency and sometimes replaced by the term cohesion (Thomas, 2012, p. 458). For the purposes of this work consistency refers to both synergy of multiple policies (horizontal consistency) and actors within the political entity (vertical consistency). Without synergy on the political level, foreign policy effectiveness is weakened due to 
competing authorities and diverging policies which might be exploited by third countries (Orenstein and Kelemen, 2007). However consistency of the policies level and single push by all actors is not sufficient to promote efficiency of EU foreign policy. For example in the analysis Daniel C. Thomas dedicated to EU influence on bilateral non-surrender agreements author finds out, that coherence itself is not sufficient to exert EU influence abroad, but may be necessary condition (Thomas, 2012, p. 472). This shifts our attention to capacities which are second key element for EU foreign and security policy efficiency.

Capacities may refer to material, political, administrative, diplomatic or other capacities. Foreign and security policy without real capacities being transformed in political outcomes is incapable and thus inefficient. It the worst case scenario it may lead to foreign and security policy underperformance or even complete failure undermining international prestige of the actor. In other words underperformance may be costly. This article focus mainly on EU military capacities which seems to be most problematic aspects within capacities, as is EU is regarded predominantly as soft power with dense political ties (see e. g. Savorskaya, 2015; Larsen, 2014; Nielsen, 2013).

Effectiveness of Foreign policy may be supported by cooperation with other partners. Mobilization of partners among friendly states, international organization or actors within the area for EU interest will lead to improved performance increase impact of Foreign policy. For this reason many civilian and military operations are open to non-EU actors and cooperation with other international organizations is inevitable and most often principal condition for success (Raăiu and Vasilean, 2009).

This model is far from being complex and to great extend simplifies the reality. However it may serve as basic approach towards analysis. For this reason article is divided in three parts, each dedicated to analysis of key variable determining foreign and security policy efficiency. Despite to several historical examples, the main focus in the article is laid down on actual developments (March 2017) in the realities of Lisbon treaty.

Hopefully, this article will contribute to existing debate about EU foreign policy effectiveness, which is well summarized by Christopher J. Bickerton (2011) and deeper analysis of the position of the EU within the international system. For decades it has been argued that EU is economic giant, political dwarf and military worm. ${ }^{2}$ This generally shared view has its roots within neo-realist perception of the EU as a soft power as defined by the Joseph Nye (2004). Nye claims that soft power is "the ability to get what you want trough attraction rather

${ }^{2}$ To my full knowledge author of this comparison is Mark Eyeskens, former Belgian Minister of Foreign Affairs, who made this statement in response to EU approach to Gulf War (see The New York Times, 25 ${ }^{\text {th }}$ January 1991). 
than coercion or payment (Nye 2004, p. x) with special reference to culture, political ideals and policies which are seen as legitimate in the eyes of others (Nye 2004, p. 11). For decades EU or EC have been area representing economic growth, freedom, democracy, human rights protection, high environmental standards and in many cases also developed social standard of well being which served as good example to other countries. However, in order to keep all the achievements of European integration and peace EU needs to develop also its hard power, including real capacities behind deterrent. This article maps current status of affairs in the dimension of policy consistency, capacities and prospects for cooperation.

\section{CONSISTENCY}

First important factor strongly influencing efficiency of any policy is the consistency. In the situations when various parts of policy are not working in the same direction towards policy goals or even worse when are going in divergent way, the efficiency is undermined by policy imbalances. In general, there are two major threats related to policy consistency: the content width of the policy and number of actors executing the policy. Policies which cover series of connected issues and are linked to number of tools are demanding in the terms effect coordination and externalities prevention. For example the state under its employment policy is motivating citizens to find a job by increasing minimal wage at the same time is increasing social contributions securing minimal life standard under its social policy. In the end both measures may have disturbing effect.

Policy consistency may be treated by the number of implementing or participating actors with different standards and approaches leading to lack of policy coordination. This may for example occur when president and prime ministers are from different political party or have competing opinion on international issues.

At the EU level we can talk about two types of political consistencies. While vertical consistency refers to policy consistency between the EU and its Member states the horizontal consistency reflects the coordination between EU policies and institutions. ${ }^{3}$ In the reality of the EU both consistencies may be easily disturbed as there are many actors involved in executing the policy. For these reason creators of treaties incorporated several articles ensuring EU Common Foreign and Security Policy consistency.

\footnotetext{
${ }^{3}$ Some authors are referring institutional consistency as separate (see Nuttal, 2005).
} 
EU foreign policy at the horizontal level is of dual nature with two methods of policy-making based on the Treaty on European Union (TEU) and the Treaty on the Functioning of the European Union (TFEU) with implications for the nature of EU foreign policy (Keukeleire and Delreaux, 2008, p. 15). Several articles in both treaties cover horizontal consistency of the policy. For example there is Article 7 TFEU which states that: "The Union shall ensure consistency between its policies and activities, taking all of its objectives into account in accordance with the principle of conferral of powers" (Article 7 TFEU). This rather general provision is further specified within Article 21(3) TEU: "The Union shall ensure consistency between the different areas of its external action and between these and its other policies. The Council and the Commission, assisted by the High Representative of the Union for Foreign Affairs and Security Policy, shall ensure that consistency and shall cooperate to that effect" (Article 21(3) TEU). In other words it ensures the consistency on the policy level and EU institutions.

The level of policy consistency at the EU level varies according to area. For example in relation to Africa, EU development policy is very consistent and complex (Olsen, 2008) and EU as a donor has central position in the World (Smith, 2013). Also in other areas such as diplomacy and conflict resolution there is considerable shift in political consistency (Mueller, 2013). Unfortunately, there are several examples challenging horizontal (or better institutional) consistency despite positive changes made by Lisbon treaty (Tomescu 2015; Ciceo, 2012). For example there are many issues in EU-Russia relations related to violation of territorial integrity in Ukraine and illegal annexation of Crimea. Russian aggressive policy resulted in several rounds of sanctions which marked new attitude towards Russia. While EU Council adopted sanctions, European Parliament passed non-legislative resolution critical towards Russian aggressive and divisive policies. Several Members of the parliament expressed that Russia is no longer strategic partner of the EU (European Parliament, 2015). The clear message to Russia has been violated by the European Commission when President Jean-Claude Juncker travelled to Saint Petersburg International Economic Forum where he delivered speech highlighting among others many positive aspects in EU-Russian relations. Commission President said: "Even when economic sanctions are in place, we must keep the door open. And if I am here with you today, it is because I want to build a bridge" (Speech by President Jean-Claude Juncker...). One day later Council decided to extend sanctions against Russia (Council Decision 2016/982). However, inconsistencies can be observed also at the vertical level.

Vertical consistency is in primary law ensured by the Article 24 TEU: „The Member States shall support the Union's external and security policy actively and 
unreservedly in a spirit of loyalty and mutual solidarity and shall comply with the Union's action in this area. The Member States shall work together to enhance and develop their mutual political solidarity. They shall refrain from any action which is contrary to the interests of the Union or likely to impair its effectiveness as a cohesive force in international relations" (Article 24 TEU). Again, the crisis in Ukraine can well demonstrate violation of vertical consistency of CFSP.

From the early beginning states were divided over approach and sanctions towards Russia and division continued years later. (Reuters, 2014). As analysis of Open Europe (2014) suggested, EU member states were divided due to geographic position, historical experience or economic dependence on Russia. Despite economic dependence there were strongly critical countries towards Russia (Baltic states or Poland) who pushed for tighter sanctions and Strong EU response (Vilson, 2015). Some states (Finland, the Netherlands, the Czech Republic or Germany adopted softly critical approach) and some had very moderate approach (Bulgaria, Luxembourg or Greece). As picture 2 suggests, states varied from complete "doves" ranked at the scale -5 to "hawks" placed at the scale at 5, with average slightly critical attitude of the EU ranked at 0,4 (Open Europe, 2014).

Spirit of loyalty and mutual solidarity has been later violated in other ways, including weapons supply to Ukraine and Russia. United Kingdom criticised planned sale of helicopter ship Mistral to Russia by France, however itself sold to Russia sniper rifles, ammunition, drones and laser technology worth of 84 million pounds (Huffington post, 2014). According to pro-Ukraine media Euromaidan Press the UK, France, Germany, the Czech Republic, Austria, Italy, Greece and Cyprus delivered arms to Russia while Finland, Poland and Lithuania supplied arms to Ukraine. The Czech Republic and UK delivered to both sides (Gallina, 2015). Unfortunately, there are no ways how to enforce Article 24 TEU as Common Foreign and Security Policy is not under jurisdiction of EU Court of Justice. 
Picture 2: Member states attitude towards Russia

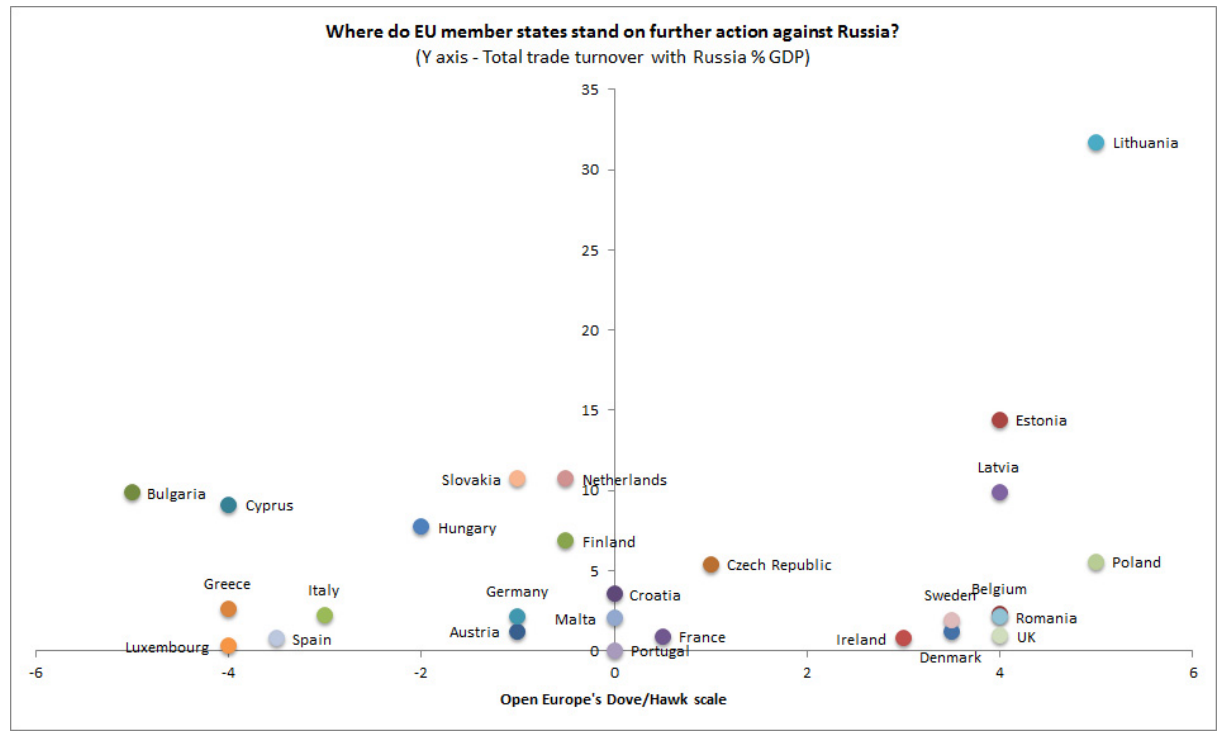

Source: Open Europe, 2014.

There are "back door" within Article 275 TFEU which states that Court of Justice of the European Union shall not have jurisdiction with respect to the provisions relating to the common foreign and security policy nor with respect to acts adopted on the basis of those provisions. It means that policy undertaken is only politically binding. Moreover, there is Declaration in the TEU concerning the common foreign and security policy, which stress that provisions related to CFSP will not affect existing legal basis, responsibilities and powers of each Member State in relation to the conduct of its foreign policy, diplomacy and relations with third country (14 Declaration TEU). The case of Ukraine is good example of EU foreign policy fragmentation. As pointed out by Mitchell A. Orenstein and Daniel R. Kelemen (2017), the EU developed strong sanction mechanism against Russia, but failed to prevent divergent national policies, leading for example in adopting new energy deals or port access for Russian naval forces (Orenstein and Kelemen, 2017, p. 88). EU thus suffers kind of disaggregation in its foreign and security policy, because central institutions are unable to prevent member states to pursue its own policies. In other words CFSP is common to the degree of member state willingness and mutual interests.

Above mentioned example of vertical inconsistency demonstrated on Ukraine crises lead just to conflicting attitude of the EU member state. However, there 
is also increasing threat of principled opposition not only towards EU SFSP, but towards EU and NATO in general. Because foreign and security policy is still mainly intergovernmental ${ }^{4}$ in its nature even negative attitude of single member state may block decision and enable to use EU capabilities. In other words, intergovernmental mechanism requiring consent of all member states and thus is very fragile and prone to paralysis.

The evil rests in national governments which had so far mainly pro-European and constructive approach. Ever since, there were competing national interests which in extreme cases resulted in paralysation of EU institutions (e.g. Empty chair crisis) or solution of international crises (e. g. War in Yugoslavia). It may seem that above mentioned examples are only product of specific historical conditions, such us rise of French nationalism or diverging interests between France and Germany. However, with growing populism affecting people and rise of radical parties the creation of anti-EU governments will be more probable and it may lead to permanent paralysis of EU decision-making.

Leaders simply can not ignore demand of domestic actors including general public (Walter 2015, p. 213). This creates the need to communicate foreign policy in order to ensure consistency at the level of domestic society and develop measures to prevent radicalism and extremism. For the majority of radical parties from both far-left and far-right is valid that they are Euro sceptic, are against NATO and against liberal-democratic values. Some show pro-Russian orientation, focus on new wave of nationalism, populism or both (see for example March 2011; Mudde 2014; Mihálik and Jankol'a 2016). The rise of extremist parties in Central and Eastern Europe caused by migration may lead to deeper alienation of citizens from EU affairs, rejection of the EU and NATO and change the region from fully integrated part of the EU into the buffer zone.

\section{CAPACITIES}

Capacities to conduct foreign and security policy are second important factor influencing efficiency. With limited resources and tools there is limited response toward challenges. UN Secretary General Kofi Annan once reportedly said: "You can do a lot with diplomacy, but, of course, you can do a lot more with diplomacy bucked up with firmness and force" (Jokela, 2011, p. 106). This is also valid for the European Union which is considered by many as economic giant, political dwarf and military worm.

${ }^{4}$ However in some areas supranational institutions such as European Commission or even European parliament strongly exert its influence and shape the agenda (Riddervold, 2016; Rosén, 2015; Mix, 2011: 399-400). 
Since the adoption of Helsinki Headline Goal in December 1999 the EU and its member states develops European military capabilities. The aim was to create a sustainable military capacity to be rapidly deployable in fulfilment of full range of Peterberg tasks. Forces shall be deployable within 60 days over the range of $4000 \mathrm{~km}$ and sustain in the field on the rotating principle. As 180000 soldiers from national capacities were allocated, the Helsinki Headline goal became developed under the Headline Goal 2010. Member states further committed to be able to respond "with swift and decisive action applying a fully coherent approach across the whole spectrum of crisis management operations covered by the Treaty on European Union"s (Council of the European Union 2009: 5). These forces are generated on the basis of EU Battle groups (Tavares, 2010, p. 134). EU Battle groups are small multi-national units intended for short-term limited interventions. However, it is complicated to deploy them due to lack of political consensus and flexibility among member states. Moreover, because of rotating principle deployment of Battle groups is costly. For example changing battle groups in Africa in every 6 months may be extremely expensive due to fuel costs and transport (Ginsberg and Penksa 2012, p. 87). EU crisis management structures for SCDP operations are understaffed and there is misbalance between military and civilian personal which limits the effectiveness and responsiveness of the EU to conduct missions (Ginsberg and Penksa, 2012, p. 87). Above mentioned examples are just few of many related to international forces and their stuffing, financing or deployment which requires unified perception of the problems and solutions.

EU developed capacities, which are sufficient to respond limited problems based on Petersberg tasks. However, greater scale conflict is far beyond EU capacities as for conducting modern warfare greater and comprehensive approach is needed including spying satellites, intelligence agencies, aircraft carriers, submarines, transport aircrafts, special forces etc. including common command structures and planning. Spying technologies and intelligence services are structured nationally and tightly connected to national security. Creation of some kind of European intelligence service is not in line with national interests and possible integration in this field may spoil privileged relations and sharing agreements with the US (Nomikos, 2005). Potential integration also poses the question on responsibility and democratic control.

Limits to deploy EU military capacities showed soon in 2011 military intervention in Libya. Before NATO took full command, several EU states to ensure no-fly zone and naval blockade when David Cameron and Nicolas Sarkozy

${ }^{5}$ So called Petersberg Tasks includes humanitarian and rescue tasks; conflict prevention and peace-keeping tasks; tasks of combat forces in crisis management, including peacemaking; joint disarmament operations; military advice and assistance tasks or post-conflict stabilisation tasks. 
failed to convince rest of EU leaders at emergency summit to enforce no-fly zone (The Guardian, 2011). Mainly France and UK decided to go further and form international coalition to execute no-fly zone: France launched Opération Harmann, UK Operation Ellamy and Belgium, Denmark, Italy, Netherlands and Spain cooperated with the US under operation Odyssey Dawn. However, US soon decided pull out from direct operations which created more pressure on European partners. There were doubts if they have enough capacities and to command and maintain no-fly zone (The Telegraph, 2011). Simply said, intergovernmental nature of CFSP prevents use of EU limited military capacities. At the time of conflict with diverging national interests EU capacities are reduced to capacities of its willing member states.

However, even capacities of individual member states are questionable due to long term limited budgets. As World Bank data shows military spending of EU countries drop from 2,8 in 1988 to current 1,5\% of GDP. If we compare EU expenditure with those of Russian Federation who spends $5 \%$ of GDP on military expenditures, with India (2,4 \% GDP) or China ( $2 \%$ GDP) we can find that EU is in military decline and the criticism of USA (which spends 3,3\% GDP) is justified. Moreover, there are more aspiring military powers in the World who become dominant in the region. Especially Saudi Arabia (13\% GDP), Iran (5,9 \% GDP) and Pakistan with 3,6 \% of GDP (World Bank 2016). Only four EU member states follow NATO Guideline to allocate $2 \%$ of its GDP to defence expenditure. Notably Greece United Kingdom, Estonia a Poland. As shown in the chart 1 majority of NATO countries are even below 1,5\% level.

Chart 1: Defence Expenditure as share of Gross Domestic Product

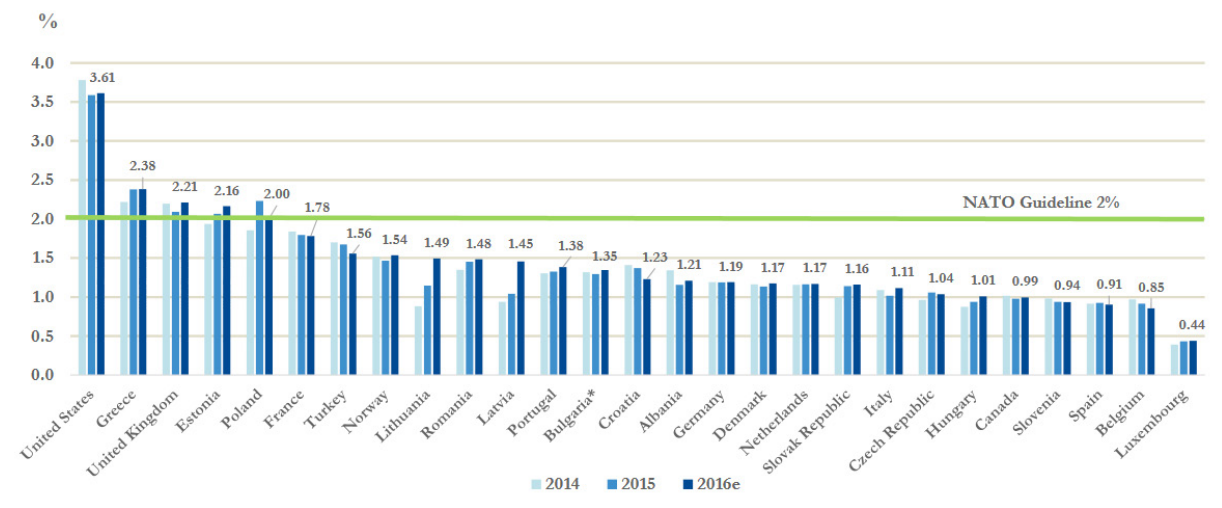

Note: Values are based on 2010 prices and exchange rates Source: NATO Communiqué PR/CP (2016) No. 116. 
Nevertheless, there are different trends in different pats o Europe. While in Southern Europe defence spending has been cut by almost $40 \%$ between 2007 and 2016 due to economic crisis and restrictive measures in Eastern Europe spending increased by 10 percent compared to 2007. It is remarkable that increase in defence budgets came after 2013 when crises in Ukraine started. Unfortunately, there is visible decreasing trend in military spending in Western and Northern Europe as well, as chart 2 shows.

Chart 2: Comparative regional defence spending in the EU $(2007=100 \%)$

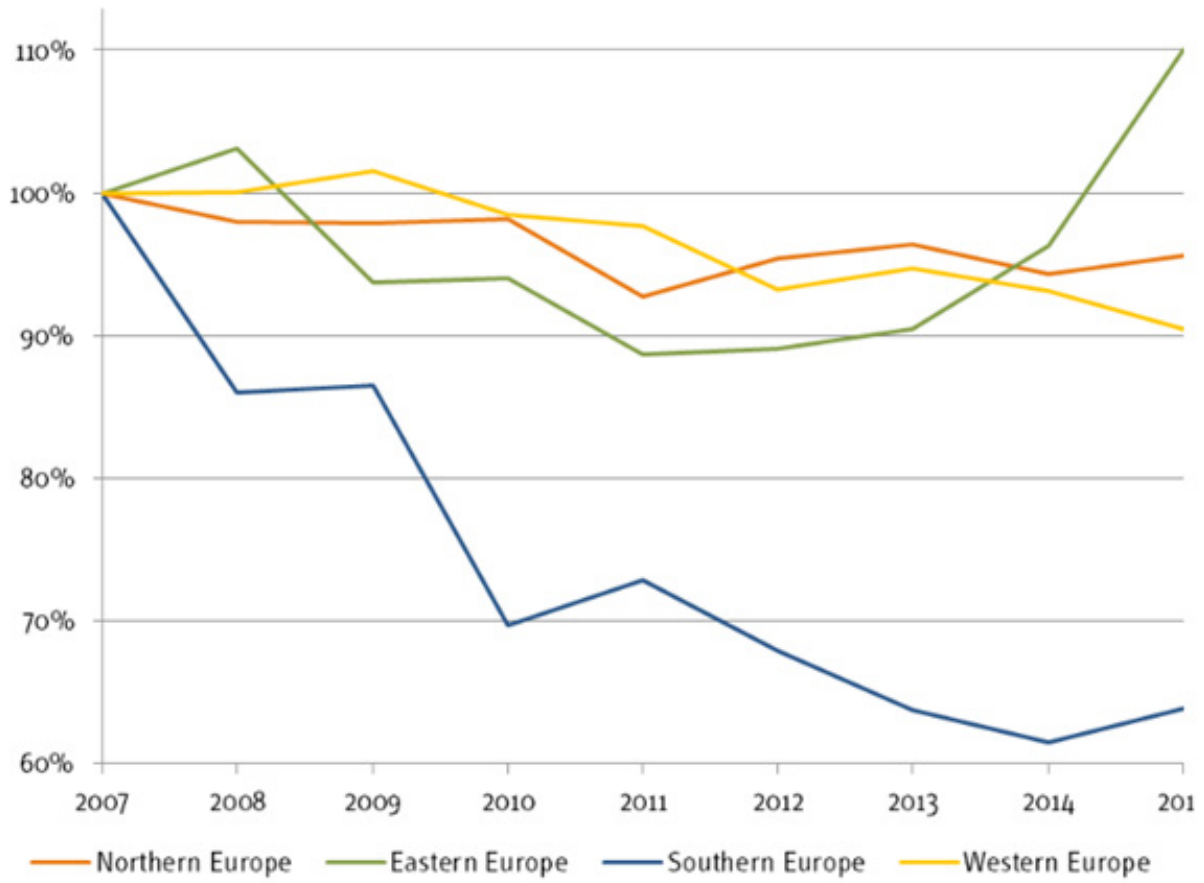

Note: Northern Europe is composed by Denmark, Estonia, Finland, Latvia, Lithuania, Sweden. Eastern Europe by Bulgaria, the Czech Republic, Hungry, Poland Romania, Slovakia. Southern Europe by Cyprus, Greece, Italy, Malta, Portugal, Slovenia, Spain. Western Europe: Austria, Belgium, France, Germany, Ireland, Luxembourg, the Netherlands and the UK.

Source: Stanley-Lockman and Wolf, 2016, p. 1.

Limited military expenditure and limited capacities both of EU and its member states posses real challenge for EU being capable actor who actively shapes global issues. Moreover, it seems that situation will not change soon as many states consider NATO guideline of $2 \%$ allocation as unrealistic goal. 
Qualitative shift might be creation of EU army, which seems to be even greater fantasy that catching up NATO requirements. ${ }^{6}$ There is a lack of willingness among neither EU member states nor favourable conditions. Estimated cost for lack of cooperation between 25 and 100 billion Euro per year (Juncker, 2016) are not enough strong stimulus without political incentives.

The most realistic attempt to create common army is dated back to Pleven plan which has been developed under extreme historic circumstances (Kunz, 1953). First, Berlin crisis and communist coup in the Czechoslovakia revealed aggressive Stalinist policy of Soviet Russia. Second, US limited its presence on the European continent due to war in Korean Peninsula and third, there was urgent need to rebuild Western Germany army and incorporate it into the European defence. After these factors weakened in 1953 Pleven plan was abandoned and severity of circumstances never repeated. Military integration has been and still is progressing in very slow pace and plans of Junker Commission to create European Defence Fund to innovate European defence industry, create permanent structured cooperation in defence capabilities or a single headquarters for EU operations is just the beginning (Juncker, 2016).

Nevertheless, above proposed changes are important due to international development. There are many states aspiring to became superpowers or at least regional powers. With growing strength of these countries there will be less space for EU influence. On the other side trend of EU military decline can be temporary. The case of Eastern European countries shows that increasing agresivity of neighbours may be positive stimulus for defence spending. However, there are also other ways how to secure EU interests. One of them is cooperation with other states and organizations which may help to overcome lack or deficiency in capacities.

\section{COOPERATION}

Due to military weakness and inconsistencies reducing effectiveness EU has to rely on cooperation with other states and organizations. However, there are new challenges in existing patterns of cooperation which has important implications for EU foreign and security policy. Three important aspects changed in 2016: there was coup attempt in Turkey which resulted in worsening of EU-Turkey relations. Presidential elections in the US lead to change in administration and new attitude of the US towards Europe. EU shared more views in common with US under Barack Obama administration than under Donald Trump. Last, there was Brexit referendum in the UK which will change cooperation patterns in security cooperation with the UK after its withdrawal from the EU.

${ }_{6}^{6}$ Article 329(2) TFEU enables enhanced cooperation within the field of CFSP, however authorisation to proceed shall be granted by a decision of the Council acting unanimously. 
Donald Trump departure from Obama policy towards Europe and transatlantic security, which indirectly addressed already at the time of inauguration: "For many decades, we've enriched foreign industry at the expense of American industry; Subsidized the armies of other countries while allowing for the very sad depletion of our military; We've defended other nation's borders while refusing to defend our own; And spent trillions of dollars overseas while America's infrastructure has fallen into disrepair and decay. We've made other countries rich while the wealth, strength, and confidence of our country has disappeared over the horizon" (White House 2017). In other words, Trump declared unwillingness to subsidize NATO and security of European countries and caused doubts among EU leaders.

During first 100 days of presidency, Trump continued in the attitude departing from EU interests. As pointed out by Kathleen R. McNamara (2017), Trump first disparaged NATO as obsolete, chastised German Chancellor Angela Merkel for her policy favourable to immigration and later seemingly advocated breakup of the European Union when he depicted it as "vehicle for Germany" (McNamara, 2017). Despite Trump meant NATO obsolence in relation to fight against terrorism and acknowledged that "NATO is still important to him" from the European perspective Trump rhetoric is bringing insecurity in transatlantic relations.

Moreover, there is another aspect of Trump policy which is seen sensitively from the European perspective. Trump on several occasions demonstrated uncritical attitude towards Russia and warm attitude towards Vladimir Putin. Server Politico uncovered dozens links between Russian and US administration, Russian connections to Trump campaign or Trump family relations towards Putin friends (Politico, 2017). In this sense the affair of Trump security advisor Michael Flynn who had to resign due to Russian ties and income from Russian sources is not surprising.

Ties with Russia and personal connections may lead to greater influence of Russia on the US policies. There is a fear among EU countries that Trump critical attitude towards NATO and warm relations with Russia may lead to changes in US soldiers allocation in Europe. According to Spiegel Magazine advisors of NATO secretary general Jens Stoltenberg prepares secret scenario for the case that US will decide to pull out soldiers from Europe (Der Spiegel 2016). In this or similar scenario replacements will require European capacities and may create "window of opportunity" for Russian forces. For this reason fear of Eastern Countries with bad historical experience with Russia is motivating factor in support of capacity development at the EU level and arms investment. 
Trump policy is not the only challenge for the future of NATO. Since the summer 2016 attempted coup in Turkey EU leaders are frustrated with country departure from democratic values and pro-European orientation. Massive cleansing in army, policy and administration including judiciary, restrictions of media, universities or other civic institutions in order to uproot elements of Gullenism alienated Turkey to the EU.

However, Turkey is key player in the Middle East and solution regional crises including those in Syria requires Turkey support. Turkey is one party in Astana peace talks together with Russia and Iran. The presence of these three countries shows who can exert some influence over situation. EU representative is missing. Turkey may well serve as the gate to Middle East for the EU and there is a positive room in keeping open relations despite diverging positions on many issues including human rights and democracy. In relation to Turkey EU is in weaker position due to two aspects. First, Turkey may abrogate March 2016 deal about refugees and let pass millions of refuges to Europe trough Balkan way which may posse great challenge to EU internal security. Second, Turkey can follow its national interest and simply bock NATO decision making process and thus enable NATO intervention which might be against interests of EU member states. The "Turkish card" represents another impetus for reliance on the EU own military capacities which will be further limited by the Brexit.

During Brexit negotiations status of the UK within EU foreign and security policy has to be renegotiated. As pointed by Richard G. Whitman (2016), there are three options for the UK to be: integrated member, associated member or detached member. As for integrated member, theUK can still participate via special status at the EU foreign and security policy making infrastructure and might engage "reverse Denmark": being outside EU but inside CFSP. Another option is to became associated partner with similar status as Norway. Under this scenario UK may join EU foreign and security policy measures with own declarations or actions. The UK involvement in other security instutions such us European Defence Agency or the EU Battlegroups will be matter of agreements. Contrary to these two options who allows certain degree of integration detached observer is not actively participating on EU institutional structure (Whitman 2016: 6). Possible settings are summarized in the Figure 1. 
Figure 1: Possible scenarios of EK and EU partnership in CFSP and CSDP

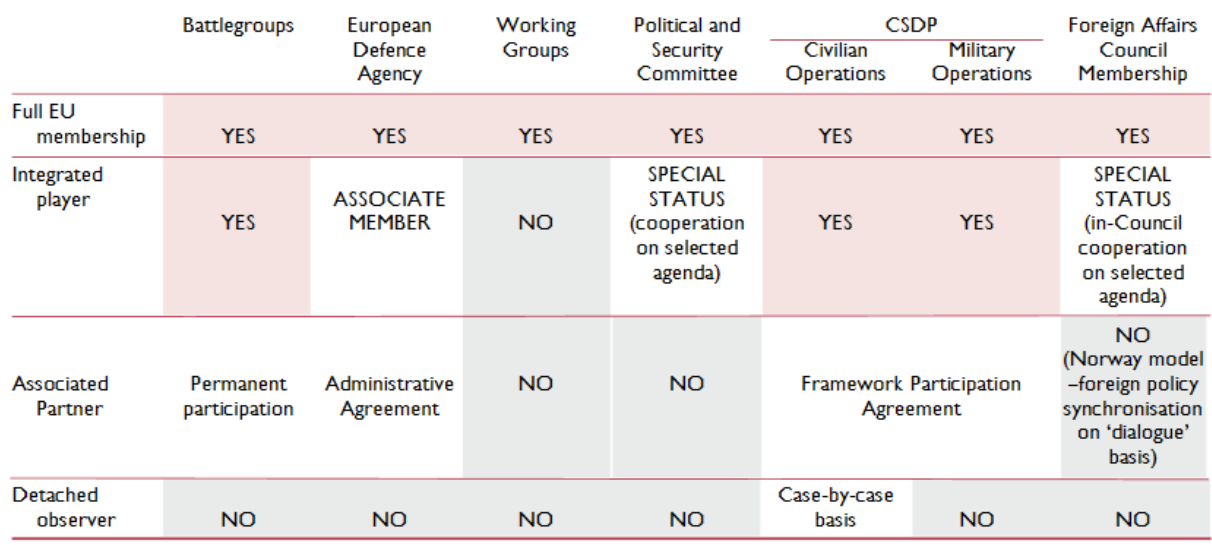

Source: Whitman, 2016, p. 7.

As the Figure 1 suggests the degree of UK departure from EU security structures will depend on the results of negotiations. However, weakening ties with the UK creates another positive influence towards EU military capacity building. Despite UK preferred NATO structures as security guarantee it has been major contributor to EU civilian and military operations. Moreover, out of $28 \mathrm{EU}$ member states UK had largest military expenditure, largest capacities including nuclear weapons and certain degree of political power as the permanent member of UN Security Council.

From the UK point of view UK may resurrect Anglosphere and push for new free trade deal. However the potential of Anglosphere is limited in both economic and military way. There is lack of proponents of resurrection and the project of Anglosphere remains more romantic than pragmatic idea (Harrison 2016: 15). In fact, there are many scenarios how EU-UK relationship in the field of foreign and security policy may develop. While some predicts continued rejection of CFSP by other member states who were hiding behind UK position, others predict new incentives for military investments and security cooperation and ongoing divide between Paris-London axis (Eilstrup-Sangiovanni, 2017). Optimists stress the possibility to unlock EU aspiration to greatness and creation of operational headquarters or NATO exclusion from EU defence (Schake, 2016)

Changes in cooperation patterns may result in further limitations of EU foreign and security policy. Limitation of ties with partners (US or UK) or different policy optics favouring divergent solutions of international problems (Turkey) may lead to conflicting attitudes and thus limited effectiveness of EU foreign and security 
policy. However, any crisis may be positive if actors involved fix inefficiencies. Due to complex nature of EU foreign and security policy this is long run.

\section{CONCLUSION}

Efficiency of EU Common Foreign and Security Policy comes from within. At the level of EU member states it is necessary to secure political and party systems in order to ensure political stability favouring cooperation at the EU level and NATO. Diverging attitudes and clashing interests may simply result in institutional paralysis and thus enable adoption of decision in the field of EU Common Foreign and Security Policy. New rise of Eurospecpticism and nationalistic populism is challenge not only for member states but may present great challenge for EU institutional setting or even EU membership.

Intergovernmental institutions are fragile due to unanimous voting and may be easily paralyzed. Supraniationalization seems to be not the solution as it opens the question of political responsibility and democratic deficit. Instead democracy checks into the system are better suitable mechanism preventing paralysis. In the reality of the EU vertical consistency seems to be enabling determinant for EU foreign and security policy however together with horizontal consistency contributes to foreign and security policy efficiency. Unfortunately, EU has still many voices which might be exploited by third countries in order to undermine EU foreign and security policy performance.

There is no efficiency without relevant capacities. EU is by many considered to be soft power, however military capacities are in long-term decline. Only four EU states follow NATO guidelines about $2 \%$ GDP spending on defence. Tensions with Russia have awaken Eastern Europe countries to catch up however general trends shows that EU is losing military power vis-á-vis emerging powers such us China, Iran or Saudi Arabia. Development of suitable capacities to tackle missions mission beyond of Petersberg task is long run. Another challenge is the utilization of existing capacities and its translation into executive policy.

Worsening relations with Turkey, cold attitude of Trump administration towards Europe, Crises in Ukraine and Brexit posses great challenge to EU foreign policy and security. However these challenges present also new driving forces for improvement of EU foreign and security policy capacities, mechanisms and patterns. Hopefully new challenging environment will lead to improvements and contribute to greater sense of community among EU member states. This "window of opportunity" shall be used for filling gaps of EU Common Foreign and Security Policy, enhancing horizontal and vertical consistency and finding new ways of cooperation with old partners. 


\section{REFERENCES}

BICKERTON, C.J. 2011. European Union Foreign Policy. From Effectiveness to Functionality, New York: Palgrave Macmillan.

CICEO, G. 2012. The Common Foreign and Security Policy and the Inexhaustible Question for its Institutional Consistency, Studia UBB. Europaea, LVII (1): 37-54.

COUNCIL DECISION (CFSP) 2016/982 of 17 June 2016 amending Decision 2014/386/CFSP concerning restrictive measures in response to the illegal annexation of Crimea and Sevastopol.

COUNCIL OF THE EUROPEAN UNION. 2009. EU Military Rapid Response Concept. Retrieved from April 3, 2017. .

DER SPIEGEL. 2016. Signal des Niedergangs. Der Spiegel Nr. 46. Retrieved from April 3, 2017. https://magazin.spiegel.de/SP/2016/46/147863976/ index.html?utm_source $=$ spon\&utm_campaign $=$ centerpage.

EILSTRUP-SANGIOVANNI, M. 2017. What Future for Europe's Security and Defense Policy? E-International Relations, 3. 1. 2017. Retrieved from April 4, 2017. http://www.e-ir.info/2017/01/03/what-future-for-europes-securityand-defense-policy/.

EUROPEAN PARLIAMENT. 2015. Russia is no longer a strategic partner of the EU, Say MEPs. 11. 6. 2015. Retrieved from April 4, 2017. http://www. europarl.europa.eu/news/en/news-room/20150604IPR62878/russia-is-nolonger-a-strategic-partner-of-the-eu-say-meps.

GALLINA, N. 2015. European countries exporting arms to Russia and to Ukraine, Euromaidan Press, 8. 3. 2015, Retrieved from April 2, 2017.http:// euromaidanpress.com/2015/03/08/european-countries-exporting-arms-torussia-and-to-ukraine/.

GINSBERG, R. H. and PENKSA, S. E. 2012. The European Union in Global Security: The Politics of Impact, New York: Palgrave Macmillan.

HARRISON, A. 2016. Brexit and Anglo-Australian Defence Policy: Back to the future? Indo-Pacific Strategic Papers, September 2016.

HUFFINGTON POST. 2014. Britain Sells £84m Of Arms To Russia And Still Has 271 Export Licenses, Despite Crimea Crisis, Huffington Post, 5. 3. 2014, Retrieved from April 2, 2017. http://www.huffingtonpost.co.uk/2014/03/05/ russia-arms-trade_n_4901787.html.

JOKELA, J. 2011. Europeanisation and Foreign Policy: State Identity in Finland and Britain, New York: Routledge.

JUNCKER, J. C. 2016. State of the Union Address 2016: Towards a better Europe a Europe that protects, empowers and defends. Strasbourg, 14 September 2016. 
KEUKELEIRE, S. and DELREAUS, T. 2008. The Foreign Policy of the European Union, New York: Palgrave Macmillan.

KISSINGER, H. A. 1994. Diplomacy. New York: Simon \& Schuster.

KUNZ, J.L. 1953. Treaty Establishing the European Defense Community, The American Journal of International Law, 47 (2): 275-281.

MARCH, L. 2011. Radical Left Parties in Contemporary Europe, Abingdon: Routledge.

MCNAMARA, K. R. 2017. Trump Takes Aim at the European Union. Foreign Affairs, 24. 1. 2017.

LARSEN, H. 2014. The EU as a Normative Power and Research on External Perceptions: The Missing Link. Journal of Common Market Studies, 52 (4): 896-910.

MIHÁLIK, J. and JANKOLA, M. 2016. European Migration Crisis: Positions, polarization and conflict management of Slovak Political Parties, Baltic Journal of Law \& Politics, 9 (1): 1-25.

MIX, D. E. 2011. The European Union: Foreign and Security Policy, Current Politics and Economics of Europe, 22 (3): 373-408.

MUDDE, C. 2014. The far right and the European elections, Current History, 113 (761): 98-103.

MUELLER, P. 2013. Europe's Foreign Policy and the Middle East Peace Process: The Construction of EU Actorness in Conflict Resolution, Perspectives on European Politics and Society, 14 (1): 20-35.

NATO (2016) Communiqué de presse, PR/CP(2016)116. Retrieved from April 4, 2017. http://www.nato.int/nato_static_fl2014/assets/pdf/pdf_2016_07 /20160704_160704-pr2016-116.pdf (3.4. 2017).

NIELSEN, K.L. 2013. EU Soft Power and the Capability-Expectations Gap, Journal of Contemporary European Research, 9 (5): 723-739.

NOMIKOS, J. 2005. The European Union's Proposed Intelligence Service. World Security Network, 17. 6. 2005. Retrieved from April 2, 2017. http:// www.worldsecuritynetwork.com/Europe/john-nomikos-1/The-EuropeanUnions-Proposed-Intelligence-Service.

NUTTAL, S. 2005. Coherence and Constituency. In: HILL, Ch. and SMITH, M. (eds.). International Relations and the European Union, New York: Oxford University Press.

NYE, J. 2004. Soft Power: The Means to Success in World Politics. New York: Public Affairs.

OLSEN, G. R. 2008. Coherence, Consistency and Political Will in Foreign Policy: The European Union's Policy towards Africa, Perspectives on European Politics and Society, 9 (2): 157-171. 
ORENSTEIN, M. A. and KELEMEN, D. R. 2017. Trojan Horses in EU Foreign Policy, Journal of Common Market Studies, 55 (1): 87-102.

POLITICO. 2017. All of Trump's Russia Ties in 7 Charts. Michael Cowley, March and April 2017. Retrieved from April 3, 2017. http://www.politico. $\mathrm{com} / \mathrm{magazine} /$ story/2017/03/connections-trump-putin-russia-ties-chartflynn-page-manafort-sessions-214868.

RAĂIU, A. and VASILEAN, B. 2009. NATO and EU Military Capabilities Complementary from the perspective of participation in multinational operations, Revista Academiei Fertelor Tereste, 14 (4): 32-38.

REUTERS. 2014. Baltic states to back further Russia sanctions if Ukraine crisis does not ease. Reuters UK, 21. 6. 2014. Retrieved from April 2 , 2017. http://uk.reuters.com/article/ukraine-crisis-sanctions-balticsidUKL6N0P20CM20140621.

RIDDERVOLD, M. 2016. (Not) in the Hands of the Member States: How the European Commission Influences EU Security and Defence Policies, Journal of Common Market Studies, 54 (2): 353-369.

ROSÉN, G. 2015. EU Confidential: The European Parliament's Involvement in EU Security and Defence Policy, Journal of Common Market Studies, 53 (2): 383-398.

SAVORSKAYA, E. 2015. The Concept of the European Union's Normative Power, Baltijskij Region, 4 (26): 66-76.

SCHAKE, K. 2016. Post-Brexit Defense Policy, Foreign Policy, 25. 6. 2016. Retrieved from April 4, 2017. http://foreignpolicy.com/2016/06/25/brexitdefense-eu/.

SMITH, M. 2013. Foreign policy and development in the post-Lisbon European Union, Cambridge Review of International Affairs, 26 (3): 519-535.

SPEECH BY PRESIDENT JEAN-CLAUDE JUNCKER AT THE $20^{\mathrm{TH}}$ SAINT PETERSBURG INTERNATIONAL ECONOMIC FORUM 2016. Saint Petersburg, 16 June 2016. Retrieved from April 4, 2017. http://europa.eu/ rapid/press-release_SPEECH-16-2234_en.htm.

STANLEY-LOCKMAN, Z. and WOLF, K. 2016. European defence spending 2015: The force awakens. European Union Institute for Security Studies Brief 10 (March 2016).

TAVARES, R. 2010. Regional Security: The Capacity of International Organizations, New York: Routledge.

THE GUARDIAN. 2011. Libya no-fly zone plan rejected by EU leaders. The Guardian, 11.3. 2011. Retrieved from April 2, 2017. https://www.theguardian. com/world/2011/mar/11/libya-no-fly-zone-plan-rejected.

THE NEW YORK TIMES. 1991. WAR IN THE FULF: EUROPE; Gulf 
Fighting Shatters European's Fragile Unity. The New York Times. 25. 1. 1991. Retrieved from April 5, 2017. http://www.nytimes.com/1991/01/25/ world/war-in-the-gulf-europe-gulf-fighting-shatters-europeans-fragile-unity. html? pagewanted $=1$.

THE TELEGRAPH. 2011. Libya: Can Britain and France really run this conflict? The Telegraph, 22. 3. 2011. Retrieved from April 2, 2017. http:// www.telegraph.co.uk/comment/columnists/concoughlin/8399184/LibyaCan-Britain-and-France-really-run-this-conflict.html.

THOMAS, D. C. 2012. Still Punching below Its Weight? Coherence and Effectiveness in European Union Foreign Policy, Journal of Common Market Studies, 50 (3): 457-474.

TOMESCU, G.-V. 2015. EU in Crisis: Current Challenges in the Area of SFSP. A Legal Perspective, CKS Proceedings, 5: 868-872.

TREATY ON THE EUROPEAN UNION. OJ C 202 (2016). Retrieved from April 1, 2017. http://eur-lex.europa.eu/legal-content/EN/ TXT/?uri=OJ:C:2016:202:TOC.

TREATY ON THE FUNCIONING OF THE EUROPEAN UNION. OJ C 202 (2016). Retrieved from April 1, 2017. http://eur-lex.europa.eu/legal-content/ EN/TXT/?uri=OJ:C:2016:202:TOC.

VILSON, M. 2015. The Foreign Policy of the Baltic States and the Ukrainian Crisis: A Case of Europeanization? New Perspectives, 23 (2): 49-76.

WALTER, Aaron T. 2015. Foreign Policy: Public Opinion and Political Legacy, Slovak Journal of Political Sciences, 15 (3): 202-220.

WHITE HOUSE. 2017. The Inaugural Address. January 20, 2017. Retrieved from April 3, 2017. https://www.whitehouse.gov/inaugural-address.

WHITMAN, R. G. 2016. The UK and EU Foreign, Security and Defence Policy after Brexit: Integrated, Associated or Detached? National Institute Economic Review 238.

WORLD BANK. 2016. Military expenditure (\% of GDP). Retrieved from April 3, 2017. http://data.worldbank.org/indicator/MS.MIL.XPND.GD.ZS 